\title{
Idioventricular rhythm and shock after a honeybee sting
}

\author{
Ritmo idioventricular y shock después de un piquete de abeja
}

Desireé Franco-Lugo ${ }^{*}$, Denise A. Uribe-Vallarta ${ }^{1}$, Karen D. Bernal-Contreras ${ }^{1}$, Valerie P. Vargas-Abonce ${ }^{2}$, Enrique Soto-Pérez-De-Celis ${ }^{3}$, Jaime Rivera-Figueroa ${ }^{4}$, Daniel Cuevas-Ramos ${ }^{5}$, Francisco J. Gómez-Pérez ${ }^{5}$, and Miguel Á. Gómez-Sámano ${ }^{5}$

${ }^{1}$ Universidad Anáhuac México Norte, Ciudad de México, México; ${ }^{2}$ Universidad Autónoma Metropolitana Unidad Xochimilco, Ciudad de México, México; ${ }^{3}$ Department of Geriatrics, Instituto Nacional de Ciencias Médicas y Nutrición Salvador Zubirán, Ciudad de México, México; ${ }^{4}$ Department of Cardiology and Electrophysiology, Instituto Nacional de Ciencias Médicas y Nutrición Salvador Zubirán, Ciudad de México, México; ${ }^{5}$ Department of Endocrinology, Instituto Nacional de Ciencias Médicas y Nutrición Salvador Zubirán, Ciudad de México, México

\begin{abstract}
Objective: The objective of this study was to describe the case of a 19-year-old male presenting with bradycardia and hypotension after a honeybee sting making a review of the literature and pathophysiology of the cardiovascular and electrocardiogram (EKG) changes after a bee sting. Methods: The patient's airway was inspected and secured. Electrocardiogram with an idioventricular rhythm at 41' bpm. Oxygen was administered, an intravenous access was established, and the transcutaneous pacemaker leads were placed on the chest of the patient, then published guidelines management was induced. Results: The EKG showed idioventricular rhythm at a rate of 41 beats/min that resolved to a normal sinus rhythm after treatment. Conclusions: $A$ full and prompt cardiovascular evaluation should be performed in all patients presenting to the emergency department after a bee sting, and published guidelines regarding the management of bradycardia and anaphylaxis should be followed to achieve successful outcomes.
\end{abstract}

Key words: Honeybee sting. Idioventricular rhythm. Bradycardia.

\section{Resumen}

Objetivo: Describir el caso de un paciente masculino de 19 años que presenta bradicardia e hipotensión después de una picadura de abeja haciendo una revisión de la literatura y fisiopatología de los cambios cardiovasculares y electrocardiográficos después de una picadura de abeja. Métodos: Se inspeccionó y aseguró la vía aérea del paciente. Un rastreo de ECG realizado al ingreso reveló ritmo idioventricular a una ritmo de 41 latidos por minuto. Se administró oxígeno, se estableció un acceso IV y se colocaron los cables del marcapasos transcutáneo en el tórax del paciente, luego se indujo el manejo de las guías publicadas. Resultados: El electrocardiograma mostró un ritmo idioventricular a una frecuencia de 41 latidos por minuto que se resolvió a un ritmo sinusal normal después del tratamiento. Conclusiones: Se debe realizar una evaluación cardiovascular completa y rápida en todos los pacientes que se presentan al departamento de emergencias después de una picadura de abeja, y se deben seguir las pautas publicadas sobre el manejo de la bradicardia y la anafilaxia para lograr resultados exitosos.

Palabras clave: Picadura de abeja. Ritmo idioventricular. Bradicardia.

\section{Correspondence:}

*Desireé Franco-Lugo

E-mail: desireefrancolugo @ hotmail.com
Available online: 12-04-2021

Arch Cardiol Mex (Eng). 2021;91(2):156-159

www.archivoscardiologia.com 2604-7063 / @ 2020 Instituto Nacional de Cardiología Ignacio Chávez. Published by Permanyer. This is an open access article under the CC BY-NC-ND license (http://creativecommons.org/licenses/by-nc-nd/4.0/). 


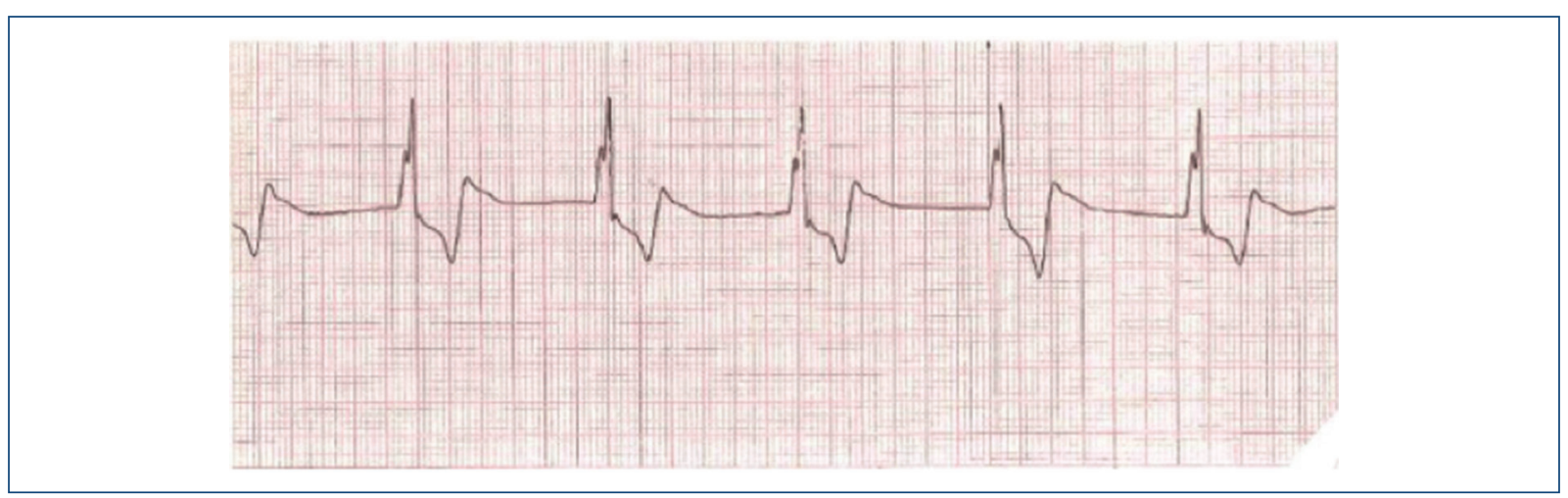

Figure 1. Admission electrocardiogram. It shows an idioventricular rhythm at 41' bpm.

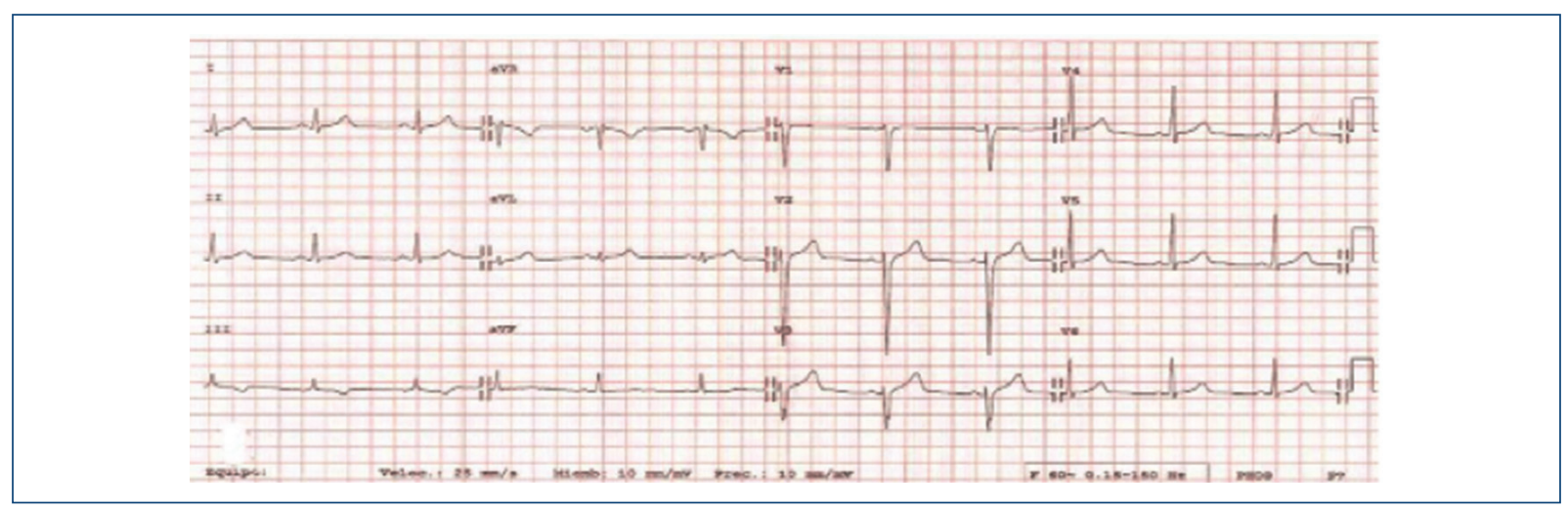

Figure 2. Post-treatment electrocardiogram. After administration of $0.5 \mathrm{mg}$ intravenous of atropine, it is seen a normal sinus rhythm with $65^{\prime}$ bpm.

\section{Introduction}

We describe the case of a 19-year-old male patient who presented with an idioventricular rhythm after a honeybee sting. The literature review has shown that the venom content of Apis mellifera can cause from local non-allergic to anaphylactic shock reactions.

\section{Case presentation}

A previously healthy 19 -year-old man was admitted to our emergency department with generalized paresthesias, dyspnea, facial edema, and a rash in his neck and both upper extremities. On arrival, the patient was conscious and able to move his extremities.

\section{Patient history before admission}

Our patient had been stung by a honeybee in the neck 30 min before admission; he reported a previous anaphylactic shock following a bee sting 7 years earlier. On admission, his blood pressure was $60 / 40 \mathrm{mmHg}$, his pulse was regular at a rate of 40 beats $/ \mathrm{min}$, and his temperature was $37^{\circ} \mathrm{C}$ and pulse oximetry in $92 \%$.

\section{Hospital management}

The patient's airway was inspected and secured. An electrocardiogram (EKG) tracing taken on admission revealed idioventricular rhythm at a rate of 41 beats/ min (Fig. 1). Oxygen was administered, an intravenous (IV) access was established, and the transcutaneous pacemaker leads were placed on the chest of the patient; then, atropine was administered at a dose of 0.5 $\mathrm{mg}$ IV, producing a change in the EKG tracing, which showed $P$ waves and a heart rate of 65 beats $/ \mathrm{min}$. Two liters of normal saline, hydrocortisone, ranitidine, and chlorpheniramine were also administered intravenously. After these, the 12 lead EKG showed normal sinus 
rhythm at a rate of 65 beats/min (Fig. 2) and blood pressure rose to $120 / 70 \mathrm{mmHg}$. Blood test results were all within the normal range. The patient remained under observation for $24 \mathrm{~h}$, after which he was uneventfully discharged home.

\section{Discussion}

Honeybee (Apis mellifera) venom can cause a variety of reactions ranging from local non-allergic reactions (pain and erythematous lesions) to anaphylactic (laryngeal edema, bronchospasm, and hypotension) ${ }^{1}$ or in some rare cases toxic reactions (myocardial infarction, acute renal injury, and encephalopathy) ${ }^{2}$, the local effects are due to the toxic component of the venom, while the most severe reactions are related to an allergic systemic response ${ }^{3}$. In the United States, hornets, bees, and wasps are the cause of $70 \%$ of all venomous animal-related fatalities, causing an average of 48 deaths/year ${ }^{4}$. In Mexico between 1998 and 2009, there were 480 deaths associated with bee stings $^{5}$. Cardiovascular events after bee stings have mostly been described in relation to anaphylactic shock, although several reports have underlined the relevance of the direct action of the venom on the heart and the coronary circulation, even causing myocardial infarction $^{6-9}$.

Honeybee venom is composed of a mix of peptides, amines, and enzymes that include apamin (a small neurotoxin that blocks $\mathrm{Ca}^{2+}$ dependent $\mathrm{K}^{+}$channels $)^{10}$, adrenaline, noradrenaline, histamine, serotonin, and tertiapine, which may provoke myocardial ischemia and intense hypotension ${ }^{11}$. It could also be the cause of an allergic or non-allergic local reaction, anaphylaxis, or a systemic toxic reaction such as vomiting or edema ${ }^{12}$.

Animal studies have proven that on the injection of bee venom, an intense bradycardic response is elicited which, at least in part, contributes to the fall in blood pressure that characterizes anaphylaxis. This response is probably related to the direct effect of toxins on the pacemaker of the heart and is transitory and fully reversible ${ }^{13}$. In small concentrations, bee venom caused a decrease in the heart rate of an isolated toad heart and elongation of the PR interval, with marked electrocardiographic changes that included depression of the ST segment, atrioventricular conduction disturbances, and atrial arrhythmia ${ }^{14}$.

Bee stings usually cause temporary electrocardiographic changes, given the local vasoactive, cardiotoxic, or anaphylactic effects contained in their venom ${ }^{6}$.
The clinical manifestations of bee stings can be local or generalized. Local reactions mainly include pain, swelling, and pruritus at the site of the sting and are self limiting ${ }^{15}$. Generalized reactions, including anaphylactic shock and cardiovascular effects, usually present within the first 30 min after the sting and can cause urticaria, rash, breathlessness, wheezing, airway edema, weakness, anxiety, and confusion ${ }^{16}$.

\section{Treatment}

Recommendations for the treatment go from the inspection of the site to remove any residue as they can form a portal for entry of germs and bacteria, cold ice, or compresses which should be administered to control the local reaction, as well as the administration of oxygen and fluids intravenously to avoid shock and hypotension ${ }^{17}$. The antihistaminics and epinephrine should be administered; in case, the patient has a known allergy. Some patients have required permanent pacemaker after a bee sting ${ }^{18}$. In the case of our patient, atropine was administered initially to treat the rhythm abnormalities observed in the EKG tracing, with successful results. Continuous observation for $24 \mathrm{~h}$ revealed no further EKG abnormalities and the rest of the manifestations caused by the bee sting resolved after the administration of histamine receptor blockers. It is important to know that bee stings can present with idioventricular rhythm.

\section{Conclusions}

Although bee stings are seldom lethal, they represent the first cause of death from venomous animal exposure in the United States. A full and prompt cardiovascular evaluation should be performed in all patients presenting to the emergency department after a bee sting, and published guidelines regarding the management of bradycardia and anaphylaxis should be followed to achieve successful outcomes.

\section{Acknowledgments}

MAGS would like to acknowledge Luz del Carmen Abascal Olascoaga for her support.

\section{Funding}

The present investigation has not received any specific scholarship from the public, commercial, or non-profit agencies. 


\section{Conflicts of interest}

None.

\section{Ethical disclosures}

Protection of human and animal subjects. The authors declare that no experiments were performed on humans or animals for this study.

Confidentiality of data. The authors declare that they have followed the protocols of their work center on the publication of the patient data.

Right to privacy and informed consent. The authors declare that no patient data appear in this article.

\section{References}

1. Ciszowski K, Mietka-Ciszowska A. Hymenoptera stings. Prz Lek. 2007;64:282-9.

2. Mingomataj EÇ, Bakiri $A H$, Ibranji $A$, Sturm GJ. Unusual reactions to hymenoptera stings: what should we keep in mind? Clin Rev Allergy Immunol. 2014:47:91-9.

3. Brown TC. Reactions to honeybee stings: an allergic prospective. Curr Opin Allergy Clin Immunol. 2013;13:365-71.

4. Langley RL. Animal-related fatalities in the United States-an update. Wilderness Environ Med. 2005;16:67-74.
5. Becerril-Ángeles M, Núñez-Velázquez M, Arias-Martìnez MI, Grupo del Programa de Control de la Abeja Africanizada, SAGARPA. Mortality related to honey-bee stings in Mexico from 1988 to 2009. Rev Alerg Mex. 2013;60:58-62.

6. Puvanalingam A, Karpagam $P$, Sundar C, Venkatesan S, Ragunanthanan S. Myocardial infarction following bee sting. J Assoc Physicians India. 2014;62:738-40.

7. Scherbak D, Lazkani M, Sparacino N, Loli A. Kounis syndrome: a stinging case of ST-elevation myocardial infarction. Heart Lung Circ. 2015;24:e48-50.

8. Puttegowda B, Chikkabasavaiah N, Basavappa R, Khateeb ST. Acute myocardial infarction following honeybee sting. BMJ Case Rep. 2014;2014:3.

9. Murat SN, Karasu BB, Akdemir R, Kilic H, Ornek E, Ozcan O. Acute coronary syndrome triggered by honeybee sting: a case report. Emerg Med J. 2009;26:754-5.

10. Lazdunski M. Apamin, a neurotoxin specific for one class of $\mathrm{Ca2+-de-}$ pendent K+channels. Cell Calcium. 1983;4:421-8.

11. Knulst AC, de Maat-Bleeker F, Bruijnzeel-Koomen CA. Wasp and bee venom allergy. Ned Tijdschr Geneeskd. 1998;142:889-92.

12. Nisahan B, Selvaratnam G, Kumanan T. Myocardial injury following multiple bee stings. Trop Doct. 2014;44:233-4.

13. Guimarães JV, Costa RS, Machado BH, dos Reis MA. Cardiovascular profile after intravenous injection of Africanized bee venom in awake rats. Rev Inst Med Trop Sao Paulo. 2004;46:55-8.

14. Nabil ZI, Hussein AA, Zalat SM, Rakha MK. Mechanism of action of honey bee (Apis mellifera L.) venom on different types of muscles. Hum Exp Toxicol. 1998; 17:185-90

15. Przybilla B, Ruëff F. Hymenoptera venom allergy. J Dtsch Dermatol Ges. 2010;8:114-27.

16. Valentine MD. Allergy to stinging insects. Ann Allergy. 1993;70:427-32.

17. Ridolo E, Martignago I, Passalacqua G, Mauro M, Incorvaia C. Evaluation of the safety of a protocol for switching venom immunotherapy products. Ann Allergy Asthma Immunol. 2018;120:429-30.

18. Gupta PN, Kumar BK, Velappan P, Sudheer MD. Possible complication of bee stings and a review of the cardiac effects of bee stings. BMJ Case Rep. 2016;2016:bcr2015213974. 